Georgetown University Law Center

Scholarship @ GEORGETOWN LAW

2003

\title{
The Imperative of Natural Rights in Today's World
}

Randy E. Barnett

Georgetown University Law Center, rb325@law.georgetown.edu

This paper can be downloaded free of charge from:

https://scholarship.law.georgetown.edu/facpub/847

http://ssrn.com/abstract $=437400$

12 Good Soc'y, no. 3, 2003, at 3-6

This open-access article is brought to you by the Georgetown Law Library. Posted with permission of the author. Follow this and additional works at: https://scholarship.law.georgetown.edu/facpub

3 Part of the Constitutional Law Commons 


\title{
THE IMPERATIVE OF NATURAL RIGHTS IN TODAY'S WORLD
}

\author{
Randy E. Barnett
}

If there is any group that really needs to understand the concept of natural rights, it is professors of constitutional law. The document they teach was written by a generation who uniformly believed in natural rights, used the concept to justify a violent revolution from their mother country, and professed their continued commitment to natural rights long after the separation-a commitment that only intensified in the years that culminated in the Civil War and the adoption of the Fourteenth Amendment. Natural rights are enshrined in the text of the Constitution in at least two places. First, there is the Ninth Amendment that reads, "The enumeration in the Constitution of certain rights shall not be construed to deny or disparage other retained by the people." Upon the evidence there can be no doubt that the rights "retained by the people" are natural liberty rights. The Fourteenth Amendment reads, in part, "No state shall make or enforce any law which shall abridge the privileges or immunities of citizens of the United States...." The great weight of the historical evidence supports the conclusion that, in addition to certain positive rights of U.S. citizenship included in the Bill of Rights and other laws, "privileges or immunities" refers to natural retained liberty rights.

Yet few constitutional law professors know much, if anything, about this fundamental concept even as a historical matter, much less as a concept worthy of continued application in today's world. The prime evidence of their lack of knowledge is the fact that they use the terms "natural rights" and "natural law" interchangeably despite the historical and theoretical distinctness of these terms. For one thing, natural law is a much older notion than natural rights, but I will not dwell here on the intellectual history of these concepts. Nor will I attempt to do justice to the multiple variations on these concepts among philosophers. Instead, I will provide what I hope will be viewed as a readily accessible explication of these concepts that has as much practical application today as it did in the days of John Locke or James Madison. Although this is decidedly my take on natural law and natural rights, I think it is true to the heart of the concept and can be used to make sense of historical materials that are otherwise inexplicable to modern constitutional scholars. And this vision of natural rights is as important today as it was in 1776 or 1868 .

Let me begin by stressing what natural law and natural rights share in common: a basic methodology. Both natural law and natural rights are what may be called normative disciplines, by which I mean intellectual constructs used to assess how human beings ought to act in pursuit of their objectives. Both employ a "given-if-then" analysis of the following sort Given the nature of $X$, if you want to achieve Y, then you ought to do Z. Modern philosophers know this form of reasoning as a hypothetical imperative. While their method relies upon the nature both of human beings and of the world - a knowledge of which is informed by physical and other empirical sciences - natural law and natural rights theorists use this "value free" information in the service of human aspirations and goals, 
thereby combining (though not collapsing) the "is" with an "ought." (Though many versions of natural law theory also locate the goal or Y in the nature or end of human beings, the account presented here takes no stance on this further teleological claim.)

So understood, the natural law mode of reasoning can be seen as pervasive in human life. For example, it pervades the normative disciplines of agriculture, architecture, engineering, and medicine. These disciplines are normative in the sense that they instruct and guide human conduct by telling us how we ought to act. Each builds upon the knowledge conferred by the theoretical sciences, as well as on practical knowledge, to address their respective subjects: given the nature of human beings and the world in which we live, if you want to grow edible crops/build habitable dwellings/construct usable machines/heal the sick, then you ought to do $\mathrm{Z}$. Of course, the answers given in $\mathrm{Z}$ will vary with the discipline.

This makes the imperatives within these disciplines dependent on a commitment to their respective ends. The imperatives of medicine depend upon caring about making people well. The imperatives of agriculture depend on caring about producing nutritious food for human consumption. Should anyone question these ends, some other arguments need to be advanced in response (hence the further teleological claims of some natural law theories). But assuming a common concern for the ends of these disciplines, the principles they teach are as imperative as any principles ever are.

Another feature shared by natural law and natural rights analyses-and what makes it accurate to call these analyses "natural"-is the content of the X: the nature of human beings and the world in which we live. Both methods of analysis abstract from the contingencies of particular persons and circumstances to identify what persons have in common as persons, including the common problems of social life, to reach general normative conclusions about action guiding rules and principles.

So both natural law and natural rights analyses employ the reasoning: given the nature of human beings and the world in which human beings live and interact, if you want to accomplish Y, then you ought to respect principles $Z$. True, if the nature of human beings and the world are "contingent" in the sense that they could have been otherwise, then the principles yielded by natural law reasoning are contingent in this sense as well. But so long as the world is as it is (and cannot be changed by human fiat or engineering) then the principles remain fixed as well.

Of course the principles yielded by a natural law or rights analysis are not to be found in nature. They are human concepts or "constructs," but neither are they arbitrary extensions of human will. If not well-grounded in the real world, they will fail to perform their vital action-guiding function. That these principles are human "constructs" no more deprecates their functional importance, and nonarbitrary nature, than does the constructed nature of the concepts and principles of agriculture, engineering, architecture, and medicine.

What differentiates natural law from natural rights is what goes in the Y. Natural law and natural rights apply the same basic method of analysis to two distinct and different (though possibly related) questions. Natural law addresses 
the problem of how we as people ought to live our lives. So natural law addresses the question: given the nature of human beings and the world in which we live, if you want to be happy or live a good life, you ought to do Z. Those general principles to which you ought to adhere are called virtues, those general categories of actions you ought not do are called vices. On the other hand, one could also consider "natural law" to be a broader umbrella term to refer to all normative disciplines based on the nature of human beings, while the problem of life well is addressed by natural law ethics, but this is merely a semantic choice.

In contrast, the subject of natural rights attempts to discern how human social interactions should be structured so as to facilitate the pursuit of human happiness. So natural rights addresses the question: given the nature of human beings and the world in which we live, if you want a society in which persons may pursue happiness while living in close proximity to others, then you ought to do $Z$. What you ought to do $(Z)$ is properly define and respect the natural rights or liberties that enable persons to pursue happiness without interfering with the like pursuit of others with whom they interact. What you ought not do is violate these properly defined rights. The connection between these two disciplines is obvious: the pursuit of human happiness or the good life, but the problems they address are quite different Handling these distinct problems require the emphasis of different facts (in the $\mathrm{X}$ ), and the conclusions reached by each mode of analysis are as different as the conclusions reached by architecture and agriculture.

The purpose of engaging in any of these normative disciplines is to guide human conduct in highly complex world - a world too complex to understand or manipulate or navigate without the use of abstractions. Not any abstractions will do, however. At root they must be grounded on the salient facts of human existence. But these facts must be selected and honed to reveal the patterns on which decisions can be made. In short, abstractions must be chosen that reveal the order, both obvious and hidden, that lies in human nature and the world in which humans live.

In previous eras, this order was universally thought to have been created by God. Many believe this even today, or say they do. Thus a discipline like natural law or natural rights was though by its adherents to be based on something divine, just as were the disciplines of medicine, agriculture, and engineering. But the authority of natural law and natural rights did not stem from any divine fiat or will - from any sort of "divine positivism." Rather, the wisdom revealed by natural law and natural rights analyses turned on the order in the world from which generalizations can be made, and it does not really matter to this analysis where this order came from.

So it is a serious intellectual error, though one that is all to common, to associate natural law or natural rights with God or with divine will. Indeed, even natural law theorists such as Aquinas distinguished between divine law which is based on the command of God and revealed in scriptures by God's word, and natural law which is based in the order in the universe and is discovered by human reason. In contrast, human law was defined as the commands of human authorities and, where these commands do not directly reflect natural law, their imperatives must be promulgated. 
It is completely inaccurate and unfair, not to mention ungenerous, to characterize natural rights theories as reflecting something called "atomistic individualism." That term is meant to connote a view of persons as radically separated from each other and immune from the effects of others. I know of no natural rights thinker who fits this description and, if you stop to think about it, no one is ever named by those who make this charge. Or if someone is named, no quotations are provided to substantiate this description.

To the contrary, the whole point of a natural rights analysis is to address the problem of human vulnerability and interconnectedness. No one person is strong or independent enough to pursue happiness in the face of concerted opposition from the masses or from a concerted handful of other people- or from even a single obsessed or evil individual. Natural rights attempts to identify conceptually the space within which vulnerable people need to be free to make their own choices about the directions of their lives, which includes crucially the choices of how to acquire, use, and dispose of scarce physical resources. Once these rights are identified, it a somewhat but not entirely separate matter of institutional design to see how they can best be protected in a world in which others are more than willing, if given half a chance, to interfere with the well being of others.

Natural rights, therefore, do not enforce themselves. They are rather a mode of normative analysis used to evaluate and critique the positive law that is needed to reinforce them. But nevertheless, if they are correctly formulated, there are real world consequences for violating these rights. Human wellbeing will suffer and die. No society will survive as a society if these principles are disregarded completely. But they may be respected more or less fully and the welfare of those who inhabit a particular regime will prosper or suffer accordingly. If empirical demonstrations of the efficacy of particular formulations of natural rights is desired beyond the appeal of rational argument, then it may be found in comparisons between those societies who better protect these rights with those in which such rights are neglected. At the extreme, the ultimate empirical test is watching the direction the refugees flee.

Both natural law and natural rights, however, have their limits that are not always acknowledged by their adherents. Based as they are on generalizations from the particularities of a highly complex world, the principles they yield are quite abstract - too abstract, indeed, to be applied deductively to any but the most obvious of situations. Natural law reveals abstract insights into vice and virtue but the most thoughtful natural law theorists acknowledge that putting these principles into practice takes judgment, an undefinable "practical wisdom"; that living well is an art, not an empirical science.

So too with natural rights. Natural rights analysis can identify the fundamental liberties that all human beings require to pursue happiness while living in close proximity to others - the rights of several property, freedom of contract, first possession, self defense, and restitution. But there is no unique demonstrably correct way of applying these abstract rights to all but the most simple of real world situations. Lawyers are well aware of just how incredibly complex real world situations can become. The abstractions of natural rights provide easy answers to very few of the vexatious problems that confront even 
first year law students in property, torts, and contracts. Although, to be fair, the cases studied there are deliberately chosen to test the margins of our intuitions on what differentiates liberty from license.

While respect for properly formulated natural rights is necessary for a well-functioning social order, it is not sufficient. There must also exist some method for applying these abstract rights to the complexities of human life so that human beings can conform their conduct to the requirements of justice. The injunctions of natural rights must assume an understandable form. This distinct but related endeavor is known as "the rule of law." What is needed are discernable doctrines or practices by which people can order their conduct towards others and upon which they can rely in making their plans for the future. Such rules are conventional in the sense that there is no one right set of rules that will accomplish this end. These rules will vary with the particular circumstances of different societies. They need to be determined by agreement or otherwise. And so long as they do not stray outside the frame provided by abstract natural rights, they can reflect other imperatives such as the ends of fairness and efficiency.

Still, properly formulated natural rights remain a guide to the outer boundaries beyond which conventional rules of law should not extend. Natural rights prevent a completely open-ended experimentation with rules of law. They provide guidance that avoids catastrophic results without having to experience them. In sum, natural rights not only point the way to the achievement of what Hayek called the Great Society in which diverse human beings living within distinctive communities can flourish. They also prevent the infinite routes to tyranny and human misery that has been the norm, rather than the exception, of history. Social experimentation that immiserates millions need not be tried to be avoided if natural rights are understood and respected.

Therefore, while it is not absolutely necessary to understand the concept of natural rights to achieve the Great Society, it certainly helps. If nothing else it cautions intellectuals against succumbing to their natural hubris when, from the comfort of their parlors, they urge others to destroy the institutions that instantiate the principles that make social order and human flourishing possible.

Randy Barnett (rbarnett@bu.edu) is the Austin B. Fletcher Professor at Boston University School of Law. He is author of The Structure of Liberty: Justice and the Rule of Law (Oxford, 2000). His new book, Restoring the Lost Constitution: The Presumption of Liberty, will be published by Princeton University Press in February 2004. His writings can be found on his website, www.randybarnett.com. Permission to photocopy for classroom use is hereby granted. 